\title{
Micropropagation of the ornamental vulnerable bromeliads Aechmea blanchetiana and Aechmea distichantha
}

\author{
Sandra Santa-Rosa ${ }^{1}$; Fernanda VD Souza ${ }^{2}$ Ádila M Vidal ${ }^{3}$; Carlos Alberto da S Ledo² José RF de Santana $^{1}$ \\ ${ }^{1}$ UEFS-Depto. Ciências Biológicas, Av. Universitária km 03 BR116, 44031-460 Feira de Santana-BA; ${ }^{2}$ Embrapa Mandioca e Fruticultura, \\ C. Postal 007, 44380-000 Cruz das Almas-BA; ${ }^{3}$ UFRB-Depto. Ciências Agrárias, 44380-000 Cruz das Almas-BA; sandra_santarosa@, \\ yahoo.com.br; fernanda.souza@embrapa.br; amelovidal@yahoo.com.br; carlos.ledo@embrapa.br; raniere@uefs.br
}

\begin{abstract}
Aechmea blanchetiana and Aechmea distichantha are Brazilian native bromeliads with great ornamental value, although none of the species are produced commercially. Therefore, market demands are met through nature predatory exploitation. This study intended to (1) evaluate the in vitro seed germination of A. blanchetiana and A. distichantha and (2) establish micropropagation protocols for both species, aiming at producing plantlets for the market, as well as to germplasm in vitro conservation. Germination experiments were carried out in completely randomized designs with two treatments (presence and absence of light) and seven and eight replications respectively for $A$. blanchetiana and $A$. distichantha. In vitro seedlings, produced under light conditions, were used as explants in the multiplication experiment (MS medium). The experimental design was again completely randomized, with treatments in factorial 2 (NAA concentrations; 0.05 and $0.5 \mu \mathrm{M}$ ) x 2 (cytokines: BAP and KIN) x 2 (cytokine levels: 2.2 and $4.4 \mu \mathrm{M})+1$ (control with basal MS, without growth regulators), with ten replications per treatment. We evaluated fungal and bacterial contamination, total and cumulative seed germination and number of shoots per treatment in each subculture. We observed only fungal contamination and only in A. blanchetiana (14.0\%). Light favored in vitro seed germination in both species (99 and 62\% respectively for A. blanchetiana and $A$. distichantha). MS medium $+0.5 \mu \mathrm{M}$ NAA $+2.2 \mu \mathrm{M}$ BAP resulted in the highest multiplication rate for both species, with significant contrasts between this treatment and the control in both species (105.62 more shoots in A. blanchetiana; 223.80 in A. distichantha). BAP promoted the formation of rootless shoots, while kinetin favored the formation of roots rather than shoots. A. blanchetiana and A. distichantha showed 90 and $97 \%$ of survival respectively in plantlet acclimatization.
\end{abstract}

Keywords: Bromeliaceae, tissue culture, in vitro multiplication rate, growth regulators.

\begin{abstract}
RESUMO
Micropropagação das bromélias ornamentais vulneráveis Aechmea blanchetiana e Aechmea distichantha

Aechmea blanchetiana e Aechmea distichantha são bromélias nativas do Brasil, de grande valor ornamental. Não sendo produzidas comercialmente, ambas sofrem exploração predatória. Este trabalho teve como objetivos (1) avaliar a germinação de sementes in vitro de $A$. blanchetiana e $A$. distichantha e (2) estabelecer protocolos de micropropagação destas bromélias, visando a produção de mudas para atender ao mercado e à conservação in vitro. Os experimentos de germinação foram conduzidos em delineamento inteiramente casualizado, com dois tratamentos (presença e ausência de luz) e sete e oito repetições respectivamente para A. blanchetiana e $A$. distichantha. Plantas in vitro, obtidas em presença de luz, foram utilizadas como explantes no experimento de multiplicação (meio MS). $\mathrm{O}$ delineamento utilizado foi inteiramente casualizado, em fatorial 2 (concentrações de ANA: 0,05 e 0,5 $\mu \mathrm{M}$ ) x 2 (citocininas: BAP e CIN) x 2 (concentrações de citocininas: 2,2 e 4,4 $\mu \mathrm{M}$ ) + 1 (controle com meio MS básico, sem reguladores de crescimento), com 10 repetições por tratamento. Foram avaliadas as contaminações fúngica e bacteriana, germinação total e cumulativa e número de brotos por tratamento em cada subcultivo. Observou-se apenas contaminação fúngica e somente em A. blanchetiana (14,0\%). A presença de luz favoreceu a germinação de sementes in vitro de ambas as espécies (99 e 62\% para respectivamente $A$. blanchetiana e $A$. distichantha). Meio MS $+0,5 \mu \mathrm{M}$ ANA $+2,2 \mu \mathrm{M}$ BAP promoveu a maior taxa de multiplicação para ambas as espécies, com contrastes significativos entre este tratamento e o controle em ambas as espécies (105,62 brotos a mais em A. blanchetiana; 223,80 em A. distichantha). BAP promoveu a formação de brotos sem raízes, enquanto cinetina favoreceu a formação de raízes em detrimento de brotos. Na aclimatização das plântulas, A. blanchetiana e A. distichantha apresentaram 90 e $97 \%$ de sobrevivência respectivamente.
\end{abstract}

Palavras-chave: Bromeliaceae, cultura de tecidos, taxa de multiplicação, reguladores de crescimento.

(Recebido para publicação em 13 de abril de 2012; aceito em 5 de novembro de 2012) (Received on April 13, 2012; accepted on November 5, 2012)

$\mathrm{G}$ enus Aechmea is one of the largest in family Bromeliaceae. Aechmea belongs to the subfamily Bromelioideae and comprises about 240 species (Luther, 2006), from which $70 \%$ are estimated to be distributed in Brazil, having its center of diversity in the Atlantic Rainy Forest (Smith \& Downs, 1979). Most bromeliads within the genus have high ornamental potential, such as Aechmea blanchetiana and Aechmea distichantha, and thus are target of predatory exploitation.

A. blanchetiana (Figure 1A) is
Brazilian native bromeliad, terrestrial, occasionally epiphytic, perennial (Bert \& Luther, 2005) and frequent among sand coastal plants and in the Atlantic Rainy Forest in states of Bahia and Espírito Santo (Martinelli et al., 2008). The inflorescence consists of a set of red 


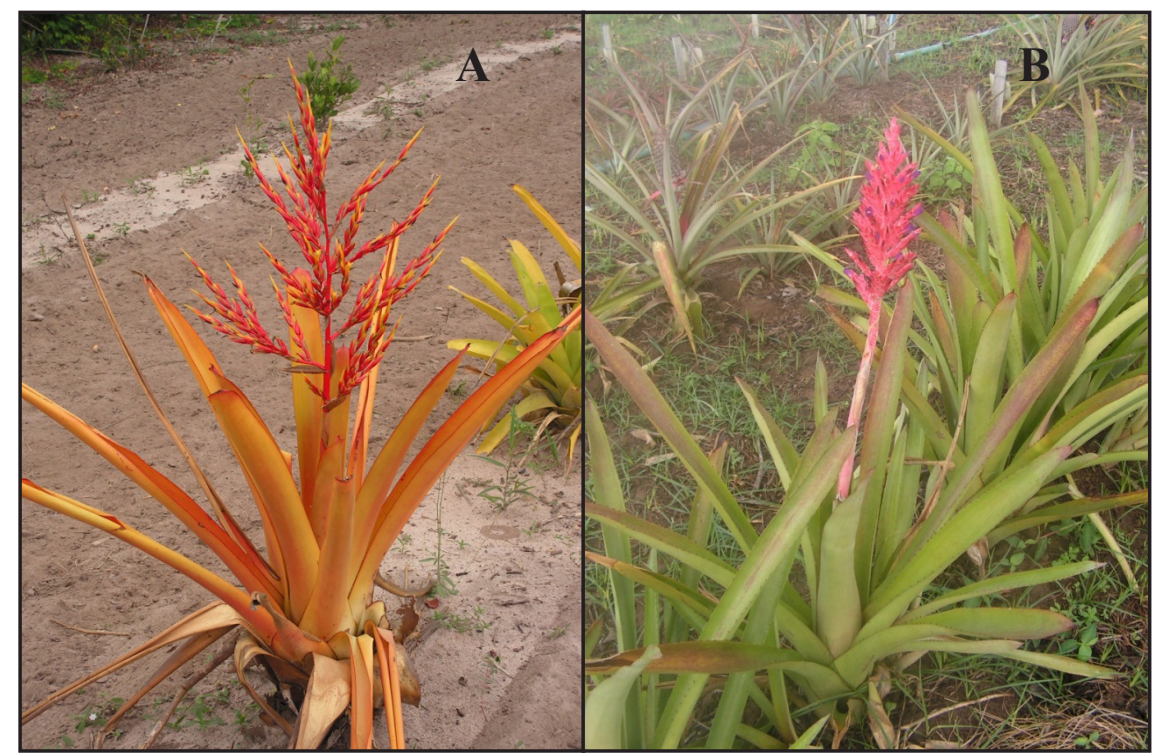

Figure 1. Flowering plants of Aechmea blanchetiana (A) and Aechmea distichantha (B) (plantas em florescimento de Aechmea blanchetiana (A) e Aechemea distichantha (B)). Cruz das Almas, Embrapa Mandioca e Fruticultura, 2009.

bracts that can last for several months. This characteristic adds to the large ornamental potential the species already has, a remarkably long postharvest life (Lorenzi \& Souza, 1998). The growing employment of $A$. blanchetiana in landscaping and gardens using plants supplied by predatory exploitation, places the species in constant threat. Kanashiro et al. (2007) stated that the lack of plant commercial production to meet market demands resulted in the presence of $A$. blanchetiana in the list of endangered species.

A. distichantha (Figure 1B), typical from the Brazilian savannah, has epiphytic, lithophytic or terrestrial habit, arched leaves reaching up to $90 \mathrm{~cm}$, and an erect rosette which lasts up to a month (Bert \& Luther, 2005). Similarly to the A. blanchetiana, the species is not grown commercially and has been used as an ornamental plant due to predatory supply, which led $A$. distichantha to the category of species vulnerable to extinction (Martinelli et al., 2008).

Taking this framework into perspective, plantlet production is the way out to simultaneously meet market demands and minimize extractive activities. Therefore, information about the propagation system of these species is required to subsidize the development of efficient micropropagation protocols. various concentrations, according to the particularities of each step of the micropropagation process (Souza et al., 2003; Droste et al., 2005; Bellintani et al., 2008; Silveira et al., 2009). As in other species, the need to develop specific in vitro protocols for Aechmea blanchetiana and A. distichantha comes mainly from the possibility that a fortuitous genotype-specific dependency appears, which would require optimization procedures to avoid compromising the results.

On the other hand, in spite of all the benefits of in vitro propagation, it is important to bring into the spot that the cloning of poorly studied species may jeopardize the preservation of genetic variability in natural populations and, in the long run, germplasm conservation, resulting in irreversible genetic erosion. Given this, seed production, seems to suit best as propagation strategy for species like Aechmea at this point. Sexual reproduction results in offspring that ensures the preservation of genetic variability and avoids gene loss (Mercier \& Nievola, 2003; Carneiro \& Mansur, 2004; Silveira et al., 2009).

Taking into account what was exposed so far, the objective of this study was to develop protocols for micropropagation of the ornamental bromeliads Aechmea blanchetiana and $A$. distichantha using plantlets originated from in vitro germination of seeds.

\section{MATERIAL AND METHODS} for several species (Mendes et al., 2007; Silva et al., 2008; Silveira et al., 2009; Santos et al., 2010; Huang et al., 2011), including A. blanchetiana (Kanashiro et al., 2007; Galvanesi et al., 2007; Chu et al., 2010).

Several factors can influence the efficiency of a micropropagation protocol. Culture medium is one of the major factors, as it paces plant growth and development (Grattapaglia \& Machado, 1998). The MS basal medium (Murashige \& Skoog, 1962) is the most used for micropropagation in bromeliads, using supplementation with auxins and cytokines, for example naphthaleneacetic acid (NAA), kinetin (KIN) or benzylaminopurine (BAP) at
In vitro seed germination of Aechmea blanchetiana and A. distichantha - Seeds from both species were taken from ripe fruits; but while for $A$. blanchetiana fruits were collected at the farm Flor de Brotas, in the city of Irará, state of Bahia, for $A$. distichantha, they were collected in the Pineapple Active Germplasm Bank of Embrapa Cassava \& Fruits. We sterilized the seeds in aseptic conditions. In a laminar flow hood, we washed them and removed residues, followed by 5 minutes immersion in $70 \%$ ethanol, 30 minutes immersion in $100 \mathrm{~mL}$ of aqueous sodium hypochlorite solution, containing $2 \%$ active chlorine with 
three drops of Tweem-20 ${ }^{\circledR}$, and three rinses using autoclaved distilled water. After, we placed the seeds in Petri dishes containing $15 \mathrm{~mL}$ of autoclaved $\left(121^{\circ} \mathrm{C}, 20 \mathrm{~min}\right) \mathrm{MS}$ medium, plus 30 $\mathrm{g} \mathrm{L}^{-1}$ sucrose, solidified with $2.4 \mathrm{~g} \mathrm{~L}^{-1}$ Phytagel $^{\circledR}, \mathrm{pH}$ adjusted to 5.8. Then, we incubated the plates in a growth chamber $\left(25 \pm 2^{\circ} \mathrm{C}, 16 \mathrm{~h}\right.$ photoperiod, photon flow density of $30 \mathrm{mmol} \mathrm{m}^{-2} \mathrm{~s}^{-1}$ ).

We counted the number of germinated seeds (radicle protrusion) daily until it became stable for five days. Following, we evaluated fungal and bacterial contamination and calculated the total percentage of germination and the cumulative germination. For analysis, we transformed the figures of percentage of germination to $\arcsin (\sqrt{x / 100})$ and compared them by Tukey's test $(\mathrm{p}>0,05)$, using the SAS statistical software (SAS Institute, 2004).

We carried out the experiments independently, one for each species, although both in a completely randomized design with two treatments (presence and absence of light) and 15-seed plates as replications. We used seven and eight replications respectively for A. blanchetiana and A. distichantha.

In vitro multiplication of axillary buds of Aechmea blanchetiana and $\boldsymbol{A}$. distichantha - We cleaned (removal of roots and residues of seed coat) 60-day old plants derived from the previous experiments, produced in the treatment with light, and placed them in test tubes (150x25 mm) containing $15 \mathrm{~mL}$ of MS, plus $30 \mathrm{~g} \mathrm{~L}^{-1}$ sucrose, solidified with $2.4 \mathrm{~g} \mathrm{~L}^{-1}$ Phytagel $^{\circledR}$, for 60 days, for plant development. After this period, we extracted $1.0 \mathrm{~cm}$-long stems from these plants to be used as explants in this experiment. We distributed the explants in flasks containing MS medium supplemented with $30 \mathrm{~g} \mathrm{~L}^{-1}$ sucrose and all combinations among the following factors: 0.05 and $0.5 \mu \mathrm{M}$ NAA (naphthalene acetic acid); 2.2 and 4.4 $\mu \mathrm{M}$ BAP (6-benzylaminopurine); and KIN (6-furfurylaminopurine). We used $2.4 \mathrm{~g} \mathrm{~L}^{-1}$ Phytagel $^{\circledR}$ to solidify the culture medium, adjusted its $\mathrm{pH}$ to 5.8 and autoclaved it $\left(121^{\circ} \mathrm{C}, 20 \mathrm{~min}\right.$.). We also set control treatments that consisted in growing explants of each species in the same medium, but without growth regulators. We incubated the explants in a growth chamber $\left(25 \pm 2^{\circ} \mathrm{C}, 16\right.$ $\mathrm{h}$ photoperiod, photon flow density of $30 \mathrm{mmol} \mathrm{m}^{-2} \mathrm{~s}^{-1}$ ) and performed three successive subcultures at 45-day intervals, cutting shoots longitudinally whenever possible.

We carried out the experiment in a completely randomized design, with treatments in factorial 2 (NAA concentrations) $\times 2$ (cytokines) $\times 2$ (levels of cytokines) +1 (control), with ten 1-plant flask replications. We counted the number of shoots developed per explant in each subculture. We used the Tukey's test ( $p>0.05)$ to compare means among treatments and subsequently the Dunnett's test $(\mathrm{p}>0.05)$ to contrast each mean against its respective control. We transformed the means into $\log (\mathrm{x}+$ 10) to correct data deviations from the normal distribution. All analyses were performed using the SAS statistical software (SAS Institute, 2004).

We acclimatized plantlets in a greenhouse, using the commercial substrate Plantmax ${ }^{\circledR}$, for 60 days.

\section{RESULTS AND DISCUSSION}

In vitro germination of Aechmea blanchetiana and A. distichantha Fungal contamination occurred only in seeds of $A$. blanchetiana (14.0\%) with no records of bacterial contamination in the experiments. Seeds of $A$. distichantha showed no contamination at all. In spite of the fungal growth recorded in $A$. blanchetiana, the disinfestation treatment we used can still be considered efficient.

Our results on seed contamination agreed with those of Galvanesi et al. (2007), which indicate that, in general, seed sterilization should not be an issue for those involved with bromeliad in vitro propagation. The fungal contamination we observed in A. blanchetiana is very likely related to seed handling and sterilization during inoculation. Fortes et al. (2004) stated that, despite the losses, fungi occurrence in in vitro conditions is not as important as bacteria, since preventing fungi occurrence depends only on adjusting sterilization methods. On the contrary, bacteria incidence, especially when endophytic, implies a much more complex control.

Despite the common presence of endophytes in bromeliad axillary and apical buds leading to contamination in the early stages of in vitro establishment, there are few reports of contamination rates when seeds are used as initial explants (Pereira et al., 2003). Most protocols which use seeds as explant source in bromeliads (Pickens et al., 2006; Bellintani et al., 2008; Silveira et al., 2009; Souza et al., 2009) do not report contamination.

Seed germination rate was always higher in $A$. blanchetiana than in $A$. distichantha. In addition, the total germination rate was significantly affected by light conditions: in both species, germination rates were higher in the presence than in the absence of light (99 and 94\% in presence and absence of light, respectively, for $A$. blanchetiana; and 62 and 47\% for A. distichantha), indisputably showing that light favored seed in vitro germination in both species.

Seed germination in $A$. blanchetiana started five days after sowing, regardless of the presence of light, and continued until the $10^{\text {th }}$ day after sowing for seeds placed under light and up to $15^{\text {th }}$ day

Table 1. Average number of shoots produced by Aechmea distichantha in vitro explants depending on ANA concentrations, after the third subculture (número médio de brotos produzidos por explantes in vitro de Aechmea distichantha em função da concentração de ANA, após o terceiro subcultivo). Cruz das Almas, Embrapa Mandioca e Fruticultura, 2009.

\begin{tabular}{lc}
\hline $\begin{array}{l}\text { ANA concentration } \\
(\boldsymbol{\mu M})\end{array}$ & Shoots $\left(\mathbf{n}^{\mathbf{0}}\right)^{\mathbf{1}}$ \\
\hline 0.05 & $98.62 \mathrm{~b}$ \\
0.5 & $104.59 \mathrm{a}$ \\
\hline $\mathrm{CV}(\%)$ & 15.69 \\
\hline${ }^{1}$ Analysis performed over values transformed \\
to log $(\mathrm{x}+10)$ [análise ralizada sobre valores \\
transformados em log (x + 10)]; Means \\
followed by the same letter do not differ \\
significantly from each other, Tukey's test, \\
p $>0.05$ (médias seguidas de mesma letra \\
não diferem estatisticamente entre si, teste \\
de Tukey, $\mathrm{p}>0,05)$.
\end{tabular}


Table 2. Average number of in vitro shoots produced by explants of Aechmea distichantha depending on cytokinine type and concentration, after the third subculture (número médio de brotos produzidos por explantes in vitro de Aechmea distichantha em função do tipo e concentração de citocinina, após o terceiro subcultivo). Cruz das Almas, Embrapa Mandioca e Fruticultura, 2009.

\begin{tabular}{|c|c|c|}
\hline \multirow{2}{*}{ Cytokinin } & \multicolumn{2}{|c|}{ Concentration $(\mu \mathrm{M})^{1}$} \\
\hline & 2.2 & 4.4 \\
\hline BAP & $237.30 \mathrm{aA}$ & $108.50 \mathrm{aB}$ \\
\hline KIN & $20.89 \mathrm{bA}$ & $24.22 \mathrm{bA}$ \\
\hline
\end{tabular}

${ }^{1}$ Analysis performed over values transformed to $\log (\mathrm{x}+10)$ [análise realizada sobre valores transformados em $\log (x+10)]$; Means followed by the same capital letter in the line and small letter in the column do not differ significantly from each other, Tukey's test, $p>0.05$ (médias seguidas de mesma letra maiúscula na linha e minúscula na coluna não diferem estatisticamente entre si, teste de Tukey, $\mathrm{p}>0,05$ ).

Table 3. Difference in number of shoots between A. blanchetiana e A. distichantha explants grown in $\mathrm{MS}^{1}$ medium modified with growth regulators and in basal $\mathrm{MS}^{1}$ (diferença em número de brotos entre explantes de $A$. blanchetiana e $A$. distichantha cultivados em meio $\mathrm{MS}^{1}$ adicionado de reguladores de crescimento e em meio $\mathrm{MS}^{1}$ básico). Cruz das Almas, Embrapa Mandioca e Fruticultura, 2009.

\begin{tabular}{lcc}
\hline MS $^{1}$ medium + growth regulartors $\mathbf{x}$ & \multicolumn{2}{c}{ Difference in number of shoots } \\
\cline { 2 - 3 } Basal MS & A. blanchetiana & A. distichantha \\
\hline $\mathrm{NAA}^{2}(0,05 \mu \mathrm{M})+\mathrm{BAP}^{3}(2,2 \mu \mathrm{M}) \times$ Basal & $63.51^{\text {ns }}$ & $237.40^{*}$ \\
$\mathrm{NAA}^{2}(0,05 \mu \mathrm{M})+\mathrm{BAP}^{3}(4,4 \mu \mathrm{M}) \times$ Basal & $89.71^{*}$ & $92.10^{*}$ \\
$\mathrm{NAA}^{2}(0,05 \mu \mathrm{M})+\mathrm{KIN}^{4}(2,2 \mu \mathrm{M}) \times$ Basal & $45.11^{\text {ns }}$ & $3.52^{\text {ns }}$ \\
$\mathrm{NAA}^{2}(0,05 \mu \mathrm{M})+\mathrm{KIN}^{4}(4,4 \mu \mathrm{M}) \times$ Basal & $51.63^{\text {ns }}$ & $9.30^{\text {ns }}$ \\
$\mathrm{NAA}^{2}(0,5 \mu \mathrm{M})+\mathrm{BAP}^{3}(2,2 \mu \mathrm{M}) \times$ Basal & $105.62^{*}$ & $223.80^{*}$ \\
$\mathrm{NAA}^{2}(0,5 \mu \mathrm{M})+\mathrm{BAP}^{3}(4,4 \mu \mathrm{M}) \times$ Basal & $61.43^{\text {ns }}$ & $111.50^{*}$ \\
$\mathrm{NAA}^{2}(0,5 \mu \mathrm{M})+\mathrm{KIN}^{4}(2,2 \mu \mathrm{M}) \times$ Basal & $46.62^{\text {ns }}$ & $24.10^{*}$ \\
$\mathrm{NAA}^{2}(0,5 \mu \mathrm{M})+\mathrm{KIN}^{4}(4,4 \mu \mathrm{M}) \times$ Basal & $52.51^{\text {ns }}$ & $24.86^{*}$ \\
\hline
\end{tabular}

${ }^{*}$ Significant, Dunnet's test, $\mathrm{p}>0.05$ (significativo, Teste de Dunnet, $\mathrm{p}>0,05$ ); ${ }^{\text {ns non significant }}$ (não significativo); ${ }^{1} \mathrm{MS}$ : Murashige \& Skoog.

for those in the dark. In the case of $A$. distichantha, although germination also began on the fifth day after sowing, the process went on until the $35^{\text {th }}$ and $40^{\text {th }}$ day for seeds kept under light and darkness, respectively.

Silveira et al. (2009), working with Neoglaziovia variegate in the same light conditions we report here, also observed differences in germination rate when studying seeds collected in ripe and immature fruits. These authors reported that germination was favored by light, observing $100 \%$ and $80 \%$ of radicle protrusion at the $10^{\text {th }}$ and $15^{\text {th }}$ days for mature and immature seeds, respectively. Several studies have reported germination rates between 90 and $100 \%$ within one week after sowing germination happens exclusively under light (Socolowski \& Takaki, 2004). Therefore, it is plausible to infer that $A$. blanchetiana and $A$. distichantha have phytochrome A, since seed germination occurred with or without light, although quicker when seeds were exposed to light.

It is known that water and temperature, as well as other factors, interact with each other and may interfere with the metabolic processes that result in seed germination. Furthermore, differences in germination may be characteristic to the genetic background of the species. Our results demonstrated that in vitro seed germination is effective in A. blanchetiana and A. distichantha, once starting from seeds, we obtained functional plants of $A$. blanchetiana and $A$. distichantha respectively 25 and 45 days after seed sowing in culture medium.

\section{In vitro multiplication of axillary} buds of Aechmea blanchetiana and $A$. distichantha - Although we observed significant differences among treatments, all treatments induced the development of axillary buds. In A. blanchetiana, the cytokine type influenced significantly the number of shoots after the third subculture, with BAP, regardless of concentration, producing the best response $(38.50$ shoots). In A. distichantha, in its turn, it were NAA concentration (CA), cytokine type (CT) and concentration (CC), and the $\mathrm{CC}$ x CT interaction that significantly altered the multiplication rate of axillary buds. The divergence of results makes it clear that the morphogenetic response to changes in explant growth conditions was species-specific.

Shoot production in A. distichantha reached the maximum (104.59) at 0.5 $\mu$ M NAA (Table 1). When we unfold the interaction CC x CT, we saw that shoot yield (237.30) reached the highest at 2.2 $\mu \mathrm{M}$ BAP, decreasing to 108.50 shoots when we doubled BAP concentration. These results suggest that BAP had an inhibitory effect when used in the highest concentration, unlike what we observed with KIN. Nevertheless, it is worth mentioning that the number of shoots obtained with KIN was much 
lower than those observed with BAP (Table 2).

In $A$. blanchetiana, the contrasts between the control and treatments 0.05 $\mu \mathrm{M} \mathrm{NAA}+4.4 \mu \mathrm{M}$ and $0.5 \mu \mathrm{M}$ NAA $\mathrm{BAP}+2.2 \mu \mathrm{M}$ BAP were significant, the latter showing the largest difference for number of shoots (105.62) (Table 3). In A. distichantha, all treatments contrasted significantly from the control, except treatments $0.05 \mu \mathrm{MNAA}+2.2 \mu \mathrm{M} \mathrm{KIN}$ and $0.05 \mu \mathrm{MNAA}+4.4 \mu \mathrm{M}$ KIN (Table 3). Treatments $0.05 \mu \mathrm{MNAA}+2.2 \mu \mathrm{M}$ $\mathrm{BAP}$ and $0.5 \mu \mathrm{M} \mathrm{NAA}+2.2 \mu \mathrm{M}$ BAP had the largest differences in number of shoots in relation to the control, respectively 237.40 and 223.80 . This result stressed once more the difference between species in relation to their in vitro morphogenetic responses and also the efficacy of growth regulators in boosting in vitro multiplication rates.
Despite the significant differences between the control and the treatments containing NAA and cytokines, the interaction NAA X cytokine was not significant for neither of the species. Thus, the auxin-cytokinine balance, in the concentrations used in this study, did not alter the number of shoots significantly. Other concentrations of these regulators, as well as different balances, should be tried in future
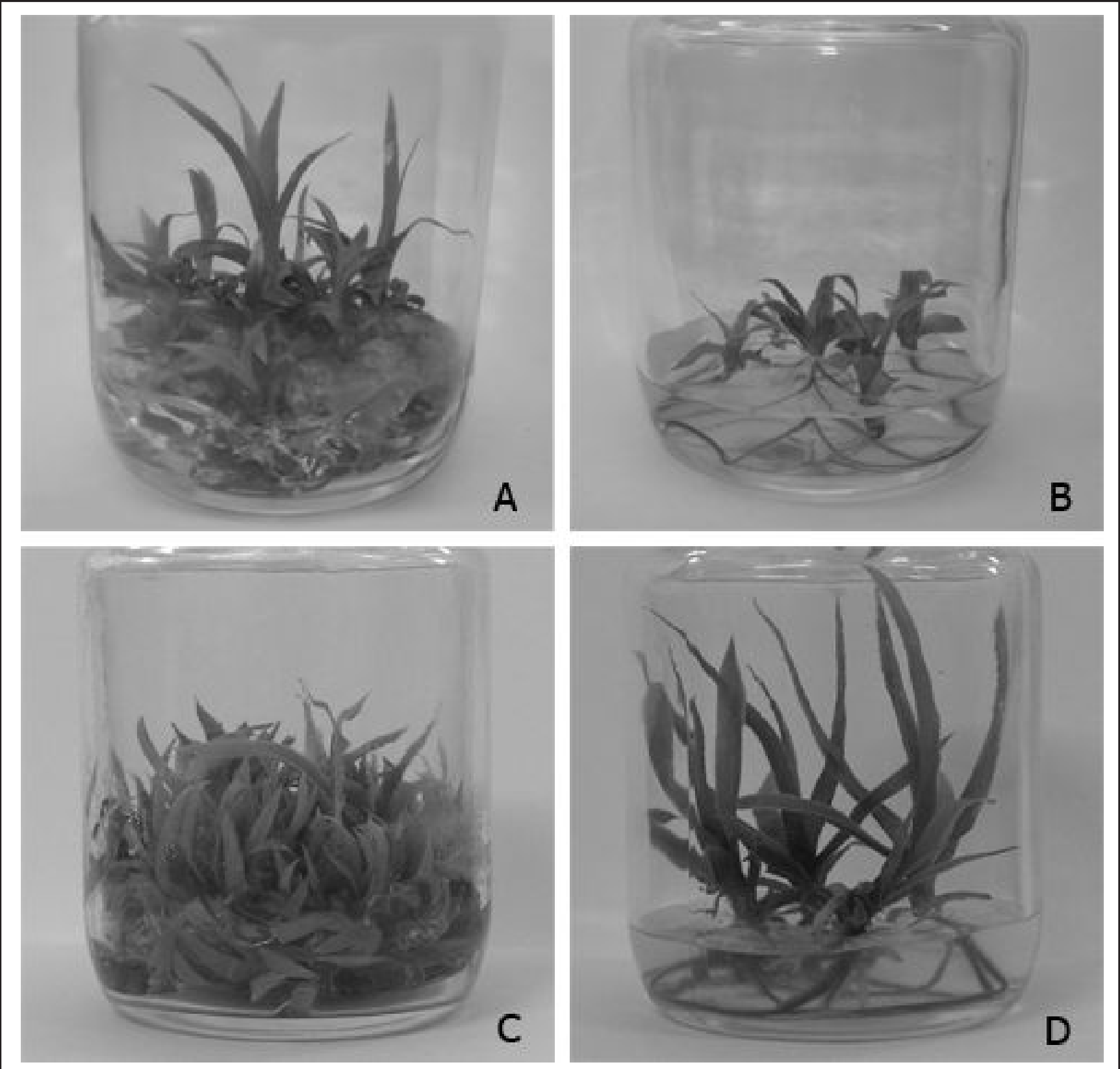

Figure 2. Aechmea blanchetiana (A and $\mathrm{B})$ and Aechmea distichantha $(\mathrm{C}$ and $\mathrm{D})$ shoots after the third subculture on medium containing BAP (A and C) and KIN (B and D) (brotos de Aechmea blanchetiana (A e B) e Aechmea distichantha (C e D) após o terceiro subcultivo, em meio contendo BAP (A e C) e CIN (B e D)). Cruz das Almas, Embrapa Mandioca e Fruticultura, 2009. 
experiments, since the increase in BAP concentration in the medium apparently inhibits shoot formation (Table 2).

Galvanesi et al. (2007) counted an average of 138.71 shoots when A. blanchetiana was grown in liquid medium supplemented with $5.0 \mathrm{mg}$ $\mathrm{L}^{-1} \mathrm{NAA}(25.0 \mu \mathrm{M})+5.0 \mathrm{mg} \mathrm{L}^{-1} \mathrm{BAP}$ $(22.0 \mu \mathrm{M})$ and 62.00 shoots in semisolid medium containing $1.0 \mathrm{mg} \mathrm{L}^{-1} \mathrm{NAA}$ $(5.0 \mu \mathrm{M})+1.0 \mathrm{mg} \mathrm{L}^{-1} \mathrm{BAP}(4.4 \mu \mathrm{M})$, in 180 days old cultures. Besides the use of liquid and semisolid medium, while we used solid medium, our work differs from Galvanesi et al. (2007) due to the much lower concentration of growth regulators we employed. These suggest that $A$. blanchetiana may present a direct relationship between cytokine concentration in the growth medium and multiplication rate. In Billbergia distachia, Mendes et al. (2007) obtained 5.1 and 5.3 shoots per stem segment in medium containing respectively the combinations $1.5 \mu \mathrm{M}$ NAA $+5 \mu \mathrm{M}$ BAP and $3.0 \mu \mathrm{M}$ NAA $+5 \mu \mathrm{M}$ BAP, after 90 days of growth. Silveira et al. (2009) in their turn reported 60.57 shoots of Neoglaziovia variegata in MS medium supplemented with 0.5 $\mu \mathrm{M}$ NAA $+4.4 \mu \mathrm{M}$ BAP, after 210 days of growth. These figures are similar to what we observed in $A$. blanchetiana (61.43) and half of what we reported for $A$. distichantha (111.50), using the same medium. Our results indicated that the reduction in BAP concentration increased the multiplication rate.

All treatments induced the development of morphologically regular shoots. However, treatments containing BAP, although producing the highest number of shoots, yielded small shoots, rootless or with few poorly developed roots. In contrast, treatments with KIN, resulted in well-developed shoots, with ordinary root systems (Figure 2). Silveira et al. (2009) reported similar behavior in the micropropagation of caroa (Neoglaziovia variegata) using BAP and KIN in the same concentrations as us. The behavior of both cytokines within the concentration range used in our study seems to be well defined for bromeliads. It is likely to be related to BAP efficiency in breaking the apical dominance at the beginning of growth, which promotes the development of a large number of lateral buds; while kinetin apparently favors root rather than shoot development. However, there is need for further studies with higher doses of kinetin to confirm these inferences.

Plantlet survival reached 90 and 97\% for A. blanchetiana and A. distichantha, respectively, 60 days after starting the acclimatization in greenhouse.

In conclusion, our results indicated that light improved the in vitro germination of $A$. blanchetiana and $A$. distichantha on MS medium, as well as the use of growth regulators enhanced the multiplication rate of both species. The highest multiplication rates for these two species were obtained on MS medium supplemented with $0.5 \mu \mathrm{M}$ $\mathrm{NAA}+2.2 \mu \mathrm{M}$ BAP, with BAP inducing the formation of rootless shoots and kinetin promoting root formation at the expense of the number of shoots. These results, along with the high plantlet survival in acclimatization, clearly show that it is possible to produce plantlets for both species in large scale and thus mitigate the predatory extraction A. blanchetiana and $A$. distichantha currently face. In addition, our results build knowledge also on methods for the in vitro conservation of these species.

\section{REFERENCES}

BELLINTANI MC; LIMA CC; BRITO AL; SANTANA JRF; DORNELLES ALC. 2007. Estabelecimento in vitro de Orthophytum mucugense Neoregelia mucugensis, bromélias endêmicas da Chapada Diamantina, Bahia Brasil. Revista Brasileira de Biociências 5: 1101-1103.

BELLINTANI MC; BRITO AL; SANTANA JRF; DORNELLES ALC. 2008. Resposta regenerativa in vitro de explantes caulinares de bromélias endêmicas da Chapada Diamantina - Bahia. Magistra 20: 328-337.

BENCKE M; DROSTE A. 2008. Otimização da micropropagação de Vriesea gigantea Gaudich. (Bromeliaceae), uma espécie ameaçada de extinção, nativa do Rio Grande do Sul, Brasil. Pesquisas, Botânica 59: 299306.

BERT TM; LUTHER HE. 2005. Aechmea information. Mulford B. Foster, Bromeliad Identification Center. Disponível em: $<\mathrm{http} / /$ fcbs.org/articles/Aechmea_spp_table.pdf $>$. Acessado em 12 de julho de 2012.

CARNEIRO LA; MANSUR E. 2004. Contribuição de metodologias in vitro para a conservação de
Bromeliaceae. Vidalia 2: 12-20.

CHU EP; TAVARES AR; KANASHIRO S; GIAMPAOLI P; YOKOTAES. 2010. Aechmea blanchetiana (Bromeliaceae) cultured in vitro. Scientia Horticulturae 125: 451-455.

DROSTE A; SILVAAM; MATOS AV; ALMEIDA JW. 2005. In vitro culture of Vriesea gigantea and Vriesea philippocoburgii: two vulnerable Bromeliads native to southern Brazil. Brazilian Archives of Biology and Technology 48: 717 722.

FORTES GL; FREITAS FO; FORTES MA; VALLS JFM. 2004. Sobrevivência de acessos de amendoim (Arachis hipogaea) através de germinação in vitro. Brasília: Embrapa Recursos Genéticos e Biotecnologia. 15p. (Boletim de Pesquisa e Desenvolvimento, 57).

GALVANESI MS; TAVARES AR; AGUIAR FFA; KANASHIRO S; CHU EP; STANCATO GC; HARDER ICF. 2007. Efeito de ANA, 6-BA e ágar na propagação in vitro de Aechmea blanchetiana (Baker) L. B. Smith, bromélia nativa da Mata Atlântica. Revista Ceres 54: 63-67.

GRATTAPAGLIA D; MACHADO MA. 1998. Micropropagação. In: TORRES AC; CALDAS LS; BUSO JA (eds). Cultura de tecidos e transformação genética de plantas. Brasília: Embrapa Informação Tecnológica/Embrapa Hortaliças. p.183-260.

HUANG PL; LIAO LJ; TSAI CC; LIU ZH. 2011. Micropropagation of bromeliad Aechmea fasciata via floral organ segments and effects of acclimatization on plantlet growth. Plant Cell Tissue and Organ Cult 105: 73-78.

KANASHIRO S; RIBEIRO RCS; GONÇÁLVES AN; DIAS CTS; JOCYS T. 2007. Efeitos de diferentes concentrações de nitrogênio no crescimento de Aechmea blanchetiana (Baker) L. B. Sm. Cultivada in vitro. Hoehnea 34: 59-66.

LORENZI H; SOUZA HM. 1998. Plantas ornamentais no Brasil: arbustivas, herbáceas e trepadeiras. Nova Odessa: Instituto Plantarum. $719 \mathrm{p}$.

LUTHER HD. 2006. An alphabetical listo of bromeliad binomials. The Bromeliad Society International. 10. ed. Florida: The Marie Selby Botanical Gardens. 116p.

MARTINELLI G; VIEIRA CM; GONZALEZ M; LEITMAN P; PIRATININGA A; COSTA AF; FORZZA RC. 2008. Bromeliaceae da Mata Atlântica Brasileira: Lista de espécies, distribuição e conservação. Rodriguésia 59: 209-258.

MENDES GC; SOARES CQG; BRAGA VF; PINTO LC; SANTANA R; VICCINI LF; PEIXOTO PHP. 2007. Multiplicação in vitro de explantes de Billbergia distachia (Vellozo) MEZ (Bromeliaceae). Revista Brasileira de Biociências 5: 972-974.

MERCIER H; NIEVOLA CC. 2003. Obtenção de bromélias in vitro como estratégia de preservação. Vidalia 1: 57-62.

MURASHIGE T; SKOOG F. 1962. A revised medium for rapid growth and biossays with tobacco tissue cultures. Physiologia Plantarum 15: 473-497.

PEREIRA JES; MATTOS MLT; FORTES GRDL. 2003. Identificação e controle com antibióticos 
de bactérias endofíticas contaminantes em explantes de batata micropropagados. Pesquisa Agropecuária Brasileira 38: 827-834.

PICKENS AK; WOLF J; AFFOLTER JM; WETZSTEIN HY. 2006. Adventious bud development and regeneration in Tillandsia eizii. In vitro Cellular \& Developmental Biology Plant 42: 348-353.

ROSA SCT; FERREIRA AG. 2001. Germinação de sementes de Plantas Medicinais Lenhosas. Acta Botânica Brasílica 15: 147-154.

SANTOS DS; TAMAKI V; NIEVOLA CC. 2010. In vitro propagation of the ornamental bromeliad Acanthostachys strobilacea (Schult. F.) Klotzsch via nodal segments. In Vitro Cellular \& Developmental Biology Plant 46: 524-229.

SAS INSTITUTE. 2004. SAS user's guide: statistic, version 9.1.3. Cary: SAS Institute. 846p.

SILVA ALL; FRANCO ETH; DORNELLES EB; GESING JPA. 2008. Micropropagação de Dyckia maritima Baker - Bromeliaceae. Heringia 63: 135-138.

SILVEIRA DG; SOUZA FVD; PELACANI CR; SOUZA AS; LEDO CAS; SANTANA JRF. 2009. Micropropagation and in vitro conservation of Neoglaziovia variegata (Arr. Cam.) Mez, a fiber producing bromeliad from Brazil. Brazilian Archives of Biology and Technology 52: 923-932.

SMITH LB; DOWNS RJ. 1979. Bromelioideae (Bromeliaceae) Flora Neotropical. New York Botanical Garden 14: 1493-2142.

SOCOLOWSKI F; TAKAKI M. 2004. Germination of Jacaranda mimosifolia (D.
Don - Bignoniaceae) seeds: effects of light, temperature and water stress. Brazilian Archives of Biology and Technology 47: 785-792.

SOUZABM; KRAUS JE; ENDRES L; MERCIER H. 2003. Relationships between endogenous hormonal level and axillary bud development of Ananas comosus nodal segments. Plant Physiology and Biochemistry 41: 733-739.

SOUZA FVD; SOUZA AS; SANTOS-SEREJO JAS; SOUZA EH; JUNGHANS TG; SILVA MJ. 2009. Micropropagação de abacaxizeiro e outras bromélias. In: JUNGHANS TG; SOUZA AS (Eds.). Aspectos práticos da micropropagação de plantas. Cruz das Almas: Embrapa Mandioca e Fruticultura Tropical. p. $177-205$. 